\title{
Human Rights and Jainism—A Comparative Study
}

\author{
Namrata Kothari \\ BHK Mahavidyalaya, West Bengal State University
}

\begin{abstract}
My research paper tries to investigate certain pertinent questions which are very important for the solution of today's problems which we are facing in a globalised world. They are as follows: (1) By following Jain principles, how one can promote and preserve rights of the individual; (2) In what ways Jain teachings prescribed preventive measures against the violation of human rights; (3) Chronology of Indian political thought and Comparison between Jain and Gandhian human rights. Today, we are facing the problems of infringement, misuse of rights in all walks of our life. We are confronting with the problems of social, economic, and political rights, discrimination between men and women in third world countries. Inequality is rampant. To establish equality-protection, promotion, and preservation of human rights is utmost important need of the day. It is one of ways that by following Jain teachings and principles we can be able to establish equality of rights and peace in the contemporary world. So my research paper will be aptly related with the Congress main theme, the politics in the world of inequality. My paper is an interpretative study which is viewed from the socio-political dimension not from the religious or metaphysical point of view.
\end{abstract}

Keywords: preservation, violation, principles, peace

With the widespread of democratic values, revolution in information technology and consequent rise of popular awareness and aspirations, the concept of HRs has assumed critical significance at both national and international levels. Though this concept originated in the west and got embodied in the UN Declaration in 1948, in orient also we find the essence of human rights from ancient times. However, in reality in England, it was a struggle between the barons and landed aristocracy on the one side and the king on the other. The western ideas of rights and liberties were developed in a particular socio-political framework in situation of oligarchy, feudalism, and highly restricted franchise. The Declaration of Human Rights recognizes:

(1) Right to life for everyone;

(2) No one shall be held in slavery;

(3) Equality before law;

(4) Right to work, liberty, security of human beings;

(5) Right to social security;

(6) Right to associate;

(7) Right to freedom of movement.

But since its inception, man has engaged in the struggle for rights. Today, we are facing the problems of infringement, misuse of rights in all walks of our life. We are confronting with the problems of social,

Namrata Kothari, M.A and Ph.D., Assistant Professor, BHK Mahavidyalaya, H.O.D, Department of Political Science, West Bengal State University, India; main research field: Political Philosophy, Peace Studies, Jain Studies, and Research Methodology. 
economic, and political rights, discrimination between men and women in third world countries. Inequality is rampant. To establish equality-protection, promotion and preservation of human rights is utmost important cry of the day. So one must demarcate here what are rights of human beings and how we can preserve and protect it. It leads to different opinions and different paths. In this researched paper, I look this important issue of our contemporary world through the prism of religion particularly through the lens of Jain teachings and principles which helps in establishing equality of rights and peace in the contemporary world.

But before going into that, we must have clarity and understanding between two things. One must know the similarities and differences between western and oriental concept of human rights. And without knowing the past, we cannot analyze the present. So we must have the chronological idea of the development of human rights in Indian and western political thought. And then only we can aptly make a comparative study between Jainism and Gandhism.

The term "human rights" as such is not found in traditional religions. Nevertheless, theology presents the basis for a human rights theory, whose source is supreme being, which certainly endows men and women with a worth and dignity from which there can logically flow the components of comprehensive human rights system. As regards its origin, the concept of human rights derived its inspiration from a variety of philosophical sources namely, the Greek thinkers developed the idea of "natural law" and laid down its essential features. According to Socrates, man possesses "insight" and this insight reveals to him the goodness and badness of things and makes him know the absolute and eternal moral values. The Stoic ideas of the "Universal Society of Rational Men," the Roman scholars followed the Stoics closely in stressing the fundamental resemblance and equality of men stemming from their common possession of reason and from their capacity to develop and to attain virtue notwithstanding differences in learning and ability. In the middle ages, great philosopher Thomas Aquinas reaffirmed that the "natural law" is higher than the positive law and it should be obeyed by all. The political philosophers like Hobbes, Locke, and Rousseau provided the necessary wings to the movement of freedom and liberty. Hobbes was basically a staunch supporter and believer of individual freedom and equality of man quoting that men were absolutely free and equal to each other while living in the state of nature. John Locke's theory of "Natural Law" where the rules must respect the standards evolved by a political community and Jean Jacque Rousseau's work on "Social Contract," where men united for the preservation of their rights of freedom and equality and they can enjoy their liberty, equality, and fraternity within a political set up. The Bill of Rights, 1689 was another great charter of liberty which was a statement of basic rights that Englishmen secured in their long struggle against the autocratic rule of the British Kings. It was the political theory of Locke which penetrated into North American colonies and passed through Samuel Adams and Thomas Jefferson into American Declaration of Independence in 1776. It also penetrated into France and passed through Rousseau into French Revolution of 1789. The American Declaration of Independence stated that all men are created equal and the French Declaration of Rights of citizens, issued by the constituent Assembly asserted that Men are born and remain free and equal in respect of rights. These rights are liberty, prosperity, security, and resistance to oppression. This provided further stimulus to the concept.

The Universal Declartion of Human Rights, 10th December, 1948 clearly echoes all these ideas when it states that "all men are born free and equal in dignity and rights." According to some scholars, the concept of human rights provides both the root as well as source for many religious movements such as Christianity, Judiasm and Islam. To them, human rights are new versions of "natural rights" and they are "God-given.” But the theory of "natural rights" has been severely criticized by Edmund Burke, Jeremy Bentham, Thomas H. 
Green, and the Marxists. Laski promoted the all round development of the individual in harmony with that of the society in which he is a member. But with the advent of Industrial Revolution and the emergence of capitalists markets, the foundation of modern democratic institutions was based on human rights, democracy and peace. As to Marx and Engels they rejected the theory of human rights. To them what people really want are concrete rights, which can be achieved under socialism. But despite these criticisms, it has been characterized as both "fundamental" and "alienable" in nature.

The Indian civilization and perhaps all the Oriental civilizations have traditionally failed to identify the individualistic value system imports from Europe underlying "human rights.” Because the Oriental society is a composite of units of individuals in collectivity, families, clans, and tribes-webbed together with the overlapping bonds of duties or the Dharma. It means for all round upliftment and development of individual and society. It means a code of conduct where man and women individually as well as socially does his or her duties. It is thus very wider than religion. The Indian tradition thus aims at preservation and welfare of the people by focusing on duties of individuals. But, now-a-days, due to overemphasis on rights, duties have been relegated to secondary position. In almost all spheres of life, there is rampant exploitation which has made common people merely a pawn in the chessboard of politics played by politicians and elites. After independence, the way in which the political system and public administration are operated grievously eroded the sovereignty of the people. Individual citizens have been relegated to the last position in the scheme of things. In the family too, members are fighting with each other in trivial matters.

So, it is very much relevant today to recall the message of our various texts and scriptures, which place emphasis on commitment to duties to individual in general and by the king and higher authorities in particular. On the other hand, in India, the references to several civil liberties occur as early as in the Rigveda such as Tana (body), Skridhi (dwelling house), and Jibasi (life) Jainism. In Ramayana, sage Valmiki narrated, king Rama while taking charge of the kingdom of Ayodhya, he declared, "Not to speak of friendship, affection, compassion, and all comforts, but even while renouncing, for the service of the people and the performance of duty, I will not feel any anguish and sorrow."

In Mahabharata, we find that the great battle was fought to uphold the sanctity of duty, because duty is the ideal before which all deep and strong relations look insignificant. Before Hobbes, in Mahabharata (the India epic), it described the civil liberty of the individual in a political state. Ancient Indian society was a highly structured and well-organized affair with the fundamental rights and duties not only to individuals, but also of classes, communities, and castes. Therefore, the concept of HRs is not entirely western origin nor, it is very modern.

In Kautilaya's Arthasastra, we find not only the illustration of civil and political obligations, but also a number of economic duties a king must perform. He ordains, "The king shall provide the orphan, the aged, the infirm, the afflicted and helpless with maintenance; he shall also provide subsistence to the helpless expectant mothers and also to the children they give birth to.”

In Vedas such as in scriptures like Puranas and Smiriti, it stresses on personal, household, social, national, and universal duties of an individual. The Rigveda pronounces: "O God! Make me darling of all irrespective of caste or creed by destroying hatred and malice, which inflict me and other."

The Yajurveda decries the greed of somebody else's thus: "O God! Let virtuously gotten wealth increase splendor of our home; I have destroyed the ill-gotten wealth.” 
The Athrvaveda ordains that "an individual should acquire wealth not for his selfish needs alone, but distribute that among the needy and deserving people.” It will help to reduce the gap between rich and poor.

In the ancient Indian Literature, we find the prescription of four stages (Ashrams) of human life, it lays more stress on duties of the Gristhas (household). They are five in number:

(1) Worship of God;

(2) The study of the Vedas;

(3) Respect for forefathers;

(4) Mercy for the entire world;

(5) Magnamity for the entire human being.

These ideas are psychological profound and they do influence the mind and body of the individual who follow it.

But Indian thinking about human rights was influenced with the advent of Muslims rule in India. Islam does not believe in the Varnashram Dharma; it treats women less equal than men. According to the Islamic law (Shariat), one man is equal to that of five women. By pronouncing the word "Talaqu," men divorce their wives at their own just will and women lose all the rights to her husband. Women have to cover her face and body by Burqua (black long cover) because they are not supposed to show their face in public. All these weaken the position of women in the society and it also effects the beautiful Hindu women, who too use veil to save themselves from the preying eyes of Muslim rules. All these factors contributed to violation of HRs and dignity of women in India. In ancient Hindu Society we find the names of Gargi, Maitrayi who were permitted to question even their very learned husbands like Yajanvalkaya. However, ruler like Akbar who granted not only religions freedom to the people but also introduced a synthetic religion called Din-i-Ilahi.

In India, the concept of HRs got phillip during the emergence of Bhakti movement. The poets like Rahim Khankahana, Tulsidas, Kabirdas, and Surdas et al., questioned the caste practices of Hindus and intolerance and orthodoxy among the Muslims. Parallel to Muslim rule in India, we also witnessed the rise of Sikh religion by Guru Nanak Dev, who preached equality and respect for human values and convinced his critics about the virtues of equality, tolerance, and freedom without which HRs cannot flourish in any country.

Sir Sayed Ahmed Khan, did not belong to Mughal era but his views are significant contribution to political thought relevant to the principles of Human Rights. He was the direct witness of the declining fortune of Muslim rule and the oppression of British rule. He therefore tried to bring reconciliation between the Muslims and the Britishers. He tried to convince the latter they could not be secured unless they allow to people to have some voice in governance. He founded the scientific society in 1863 with a view to propagate modern education among the Muslim so that they can be aware with their rights and dignity.

Finally, we must draw a reference to modern and contemporary thinkers and activists like Gandhi otherwise our discussion on human rights will not be complete. Gandhiji approaches towards the concept of Human Rights through the prism of human values and concerns rather than a selfish paradigm of rights at the cost of duties. To him, human beings can commit mistakes and atrocities but even the most brutal of human beings cannot disown spiritual element in them. He declares "What distinguishes a human being from a brute creative is the self-conscious impulse to realize the divinity inherent in him." He writes, "we were born with brute strength, but we were born in order to realize God who dwells in us. That indeed is the privilege of man and it distinguishes him from the brute creation.” He believed that through proper education and training human beings are motivated to perform their duties, the rights of others will be automatically protected. As 
regards social inequality, he was a staunch critic of untouchability and he always tries to improve their condition. He strongly believed in the abolition of caste system and advocated inter-caste marriages, inter-caste dining.

There are two main aspects of Human Rights: (a) Promotion and preservation of those rights, and (b) Preventive measure against violation of Human Rights. In view of these developments, we can now examine the elements and essence of Human Rights as implied in Jainism. Jainism is based on certain beliefs and pillars which, when explained in socio-political perspective, might add zest to its faith in the basic rights and privileges of human beings. These have by the way been the conditions for maintaining Human Rights.

Mahavira, the prophet of Jainism (6th century B.C.), advocated the equality of privileges and the universal brotherhood of man. And precisely herein is to be traced and found the essence of Human Rights that Jainism stresses and believes in. To some, Jainism is essentially a revolt against some of the fundamental issues of Vedic religion. But this observation is disputed by S. R. Banerjee who thinks Jainism should instead be treated as one of the ways of interpreting human life and society, and from that point of view it is unique. As such Jainism does not emphasize liberalism but it focuses on humanism and ultimately it comes close to liberal outlook. And for protecting, Jainism speaks of certain conditions necessary for the fulfillment of Human Rights.

In order to be worth its meaning, Human Rights can be enjoyed only in a society based on the recognition of a set of principles like free thinking, liberalism, non-encroachment on others' right, equality etc. In Jainism, we find an appreciation of them and a visualization of a democratic society. It conceptualizes an egalitarian society based on the basic principle of non-violence only to attain a state of equilibrium, moral excellence, and social peace. Its three main pillars—non-violence, tolerance and equality-may now be interpreted to show its unqualified faith in Human Rights. Therefore, one can say these are the conditions necessary for realization of Human Rights. Jainism does not speak of Human Rights, because the main stress of Human Rights is on individuality, individual autonomy. In Indian culture, these are absent and there the focus is on collectivity. Therefore, Indian tradition has ignored Human Rights despite its profound concern for humanism. Its essence, however, is the concern for individual and his interest. This leads to the focus on Jainism.

\section{Non-Violence (Ahimsa)}

Nothing can be more contributory to the guarantee, protection, and enhancement of Human Rights than the nullification of violence (himsa). It is in sharp contrast to non-violence. The cardinal principle of Jainism is non-violence that teaches that all forms of life human beings, animals, plants, trees, insects etc., have their origin from the same source of energy. "Not to kill any living being is the quintessence of all wisdom," says Mahavira. In Samanasuttam we find: Eyamkhunaninosaram, jam nahimsaikamcana, Ahimsasamayamceva, etavanteviyaniya $(12,147)$.

It is the essential trait of a wise man that he does not kill any living being. Certainly, one has to understand just two principles, namely, non-violence and equality (of all living beings).

One would generally do well to admit that non-violence is the manifestation of paying a tribute to nature. Human Rights being natural rights, it would be doing justice to nature and the natural truth to regard and respect them as essentials in human life. This is what Jainism intends to preach and spread.

Non-violence is not a single virtue but a combination of all virtues. Mahavira says that non-violence is identified with 60 virtuous qualities like peace, harmony, welfare, trust, fearlessness, etc. Further, Jainism believes in the principle of "live and let live." It is said that "Ahimsa or non-violence is the highest religion (ahimsa paramo dharma) as well as the highest sacrifice (ahimsa paramoyajnas)." 
This can be interpreted to show that in Jain philosophy the very thought of violence is itself a sin against the dignity of human being. And dignity is the other name of Human Rights. Therefore, non-violence involves dignity of the human being and thus upholds the cause of Human Rights for the fuller development of the self and the society at large.

Somadeva (959 A.D.) in his Upasakadhayana emphasized the positive aspect of non-violence or ahimsa which, in his opinion, is friendship ("maître") with the animals of all sorts without inflicting any harm on them or hurting them. To add to "maître" or friendship, he stressed the importance of promotion and inculcation of affection ("pramoda"), coupled with the respect for mankind as well as all beings and charity to help the needy (karunya). Also he held generous service to mankind (madhyasthya) as the highest wisdom. Along with this compassion (daya) is the guiding force of non-violence and positive way of life. It has been assigned an equally high place in Jainism "daya dharma kamulahai" "Compassion is the basis of religion."

The Jain doctrine of ahimsa is based on rational consciousness (samyaktva), and the appropriate expression of this spiritual progress is compassion. But this ethical value has been an aspect of ahimsa throughout in the pages of history. Acts of compassion are manifested in speaking out against animal sacrifice in Vedic ritual practices of ancient times, or in persuading others to refrain from killing animals for food or sport, or in activities associated with animal welfare and environment in modern times.

In this background, we may say no talk of Human Rights will be of any meaning in reality without the sense of friendship, affection, charity, etc. These are the conditions that define the atmosphere in promoting and protecting the basic rights of men. Observed strictly, non-violence would not only promote the auspicious condition for realizing Human rights, but would also act as a preventive measure, educating the people not to do anything to anybody that might amount to harm or hindrance to ones living. This is reflected in the passages of SamanSuttam: “Javantiloepana, tasaaduvathavara. Tejanamajanamva, nahane no vi ghayae” (149).

Whether knowingly or unknowingly, one should not kill living beings, mobile or immobile, in this world nor should cause them to be killed by others.

The concept of Human Rights loses its meaning and relevance in a society raged by violence. Non-violence is not only means but also an end towards creating a society, apt enough for peaceful coexistence and mutual sympathy among men; it is not only a condition for maintaining Human Rights but also an inspiration behind a nation's urge for self-determination a right per se. Having been influenced by Jainism, Gandhi, the Indian leader and the motivating force behind India's freedom struggle earnestly followed the principle of non-violence, the philosophical and moral base of his life, in the course of the struggle for independence of India from the British yoke.

It will be too simplistic to conceive the concept of non-violence (meaning not to harm others) in Jainism merely as an orthodox, rigid concept. Instead, it does have the pragmatic side that it puts emphasis on service to ask people to render it to mankind. Since some form of violence is inevitable in our life, Jainas also realize that it is not possible to live totally on the principle of non-violence. There were a number of famous Jaina generals and soldiers, who were not condemned by Jaina leaders or followers. It should be noted that there does not seem to be clear, well established guidelines on how lay Jaina followers are expected to respond to war and terrorism. It is however, no excuse to conclude that the observance of non-violence is an impossibility and the concept is to be reduced to a cliche.

Besides, we find a marked difference in the Western and Jain discussions of warfare and retaliatory violence. The discussions of just war focus on the social justification of warfare and take into consideration the 
impact of violence on society. In contrast, Jaina discussions throw light on the effects of involvement in warfare on an individual's spiritual progress and pursuit of moksa.

Hence, it is obvious that the Jaina view of life stresses care and amity in the interaction with all living beings. In principle, Jainism, naturally espouses non-violence and, therefore, some form of pacifism.

Mahavira as the living model of compassion and non-violence preached the same to his followers in the following passages:

As I feel every pain and agony from death down to the pulling of my hair; in the same way, be sure of this, all kinds of living beings feel the same pain and agony. For this reason all sorts of living beings should not be beaten, nor treated with violence, nor abused, nor tormented, nor deprived of life.

All creatures who commit sins will suffer and tremble. Considering this, a wise monk who has ceased sin... should abstain from violence with regards to moveable and immovable beings. (Shoog, Kim, "The Jain Response to Terrorism," ed. Sethia, Tara, Ahimsa, Anekanta and Jainism, Delhi: Motilal Banarsidass, 2004, 43; 44)

Therefore, the orientation of the Jaina discussion on ahimsa moves from the perspective of one's own soul and not so much from the perspective of the protection of other beings or the welfare of the community as a whole. The Jainas rightly claim that compassion towards other living beings is impossible without realizing the value of the self, the source of all spiritual wisdom. So the maxim upheld by the Jainas is "First knowledge then compassion.”

At present, we are living in an age of arms race and nuclear weapons and it is due to this that the existence of human race is in danger. Mahavira had said that there are weapons, one being more lethal and superior to the other; but nothing is superior to non-violence. It is the mutual credibility and the faith in the golden principle of "live and let live" that only can restore peace and harmony in human society—-the inherent promise for the promotion of Human Rights.

\section{Tolerance}

Human Rights will simply turn into an empty rhetoric in an intolerant society with intolerant people, which is one of the another basic tenant and teaching of Jainism. Unlike the Western world where dissenters from the theological mainstream did not fare so well and heretics were often harassed and even killed in medieval Europe, inquisitions were established to search for heretics and punish them. Seven kinds of punishment were used for this purpose, the commitment to ahimsa allowed the Jains to remain in relative harmony with others who did not share their theology. Their philosophy of "live and let live" made the Jains unique even within the context of the Indian subcontinent, which too had been often plagued by religious intolerance.

Haribhadra (700-770 C.E.) makes a plea for tolerance, writing that "various perspectives on conduct" can arise, but should not be criticized, as one cannot be informed or acquainted of all the circumstances. He advocates a stance of reconciliation and insists that it would not be proper to rebuke or revile well-intentioned people: "Hence it is not proper to refute words of reconciliation. Refuting or reviling noble people, it seems, would be worse than cutting one’s own tongue."

Tolerance can be acquired, as Jainism prescribes, through some vows and practices, which are by themselves the guarantees of some basic rights of human being. These are as follows. 


\section{Truth (Satya)}

We would be failing to respect the rights of others unless we are true to ourselves. "To speak what is not true is falsehood" (TS. 7.9; SS. 7.14). Truth (satyavrata) does not mean abstaining from the falsehood only. Its real meaning is to see the world in its real form and to manifest one's own self in its original form. The absence of artificiality is the observance of truth and it helps in attaining fearlessness. We can be so only if we avoid telling lies (Asatya), and thus uphold the wisdom of "truth" (Satya) in our life. According to Mahavira, truthfulness lies in the heart of non-violence. Those who speak untruth hurt all, and it is an act of violence in some form or other, meaning disregarding the right of free living of man. The truthful person (Satya) must be bound with qualities and virtues like accommodation, fellow feeling and empathy without which the idea of Human Rights can neither be a common affair nor a reality.

\section{Stealing (Acaurya)}

Jainism's emphasis on the right to social security by urging people to abstain from any kind of stealing is another vow of tolerance (Acaurya). "Taking anything that is not given is stealing” (TS. 7.10; SS. 7.15). Stealing is, in fact, an indirect encroachment on the living of others. The underlying spirit of it (acaurya, meaning not to steal) is that one should not encroach on the rights of others, because that would involve a kind of stealing. This is what one must always follow keeping the importance of social interest in view. Thus, respect for the rights of others is an application of the principle tolerance.

\section{Self-restraint (Brahmacharya)}

Jainism seeks to provide the right to life through another vow, Brahmacharya or self-restraint. "Coupling is carnality” (TS. 7.11; SS. 7.16).

Coupling means desire to touch each other, which arises in the minds of two people charged with lust from the rise of conduct-deluding Karma. Celibacy promotes the virtues of non-violence, truth and so on, while copulation augments their opposites because it is bound to involve killing mobile and immobile beings, speaking falsely, committing theft and indulging in possessiveness.

Mahavira says every living creature has a right to live and it is the duty of human beings to show respect towards right of all creatures. The observance of this principle might protect the people from committing many crimes and evils against man's living. It thus could create a healthy atmosphere for peaceful living in society and make people further virtuous.

\section{Self-restraint of body, mind, and speech}

As a measure of self-restraint, Jainism speaks of three forms of self-control (three guptis) - control of speech (VagGupti), control of activity of body (Kaya Gupti), and control of mind (Mano Gupti). If observed sacredly and scrupulously, these controls (three guptis) might well serve as the measures towards the prevention of human right violation in different countries of the world. It is also mentioned in the passages of SamanSuttam: "Vaya-samidi-kasayanam, dandanamtahaimdiyanapancanham. Dharana-palana-niggaha-caya-jaosamjamobhanio.”

Self-restraint consists of the keeping of five vows, observance of five rules of carefulness (samiti) subjugation of (four) passions, controlling all activities of mind, speech, and body and victory over the senses (chap. 9.V.101). 
As has been pointed earlier, Jainism is based on the principle of "live and let live," in another instance of its stress on right of every person to live as a human being with dignity and liberty. One must agree to disagree that no one should be held in slavery—-this is very significant internationally recognized Human Right. In India, the idea of this right is as old as Mahavira.

\section{Non-possession (Aparigraha)}

Jainism pays tribute to the above mentioned basic right of men through another vow, Aparigraha, which teaches one to renounce all passions for material things and own property. Property makes a man greedy and domineering. Slavery comes out of the sense of private property/possession. Hence, Jainism is averse to private property. “Clinging is possessiveness” (TS. 7.12; SS. 7.17; 175).

The principle of aparigraha is not a rigorous principle of self control or ascetic way of life. But it is a realistic, practical, and rational principle and its wide acceptance lies in its social basis. Its main emphasis is on a balanced society consisting of balanced individuals. It is a principle which not only has a place in Jain ethics or Indian ethics but it occupies a place in Christianity and Islam as well.

There are, however, certain presumptions essentially psychological in orientation for aparigraha. These are:

- The source of happiness and peace lies in the human individual within him and not outside him;

- External possessions are only meant to be used, not to be owned, i.e., ownership lies with nature (prakriti);

- The human individual has tremendous energies and potentials which are not based on external possessions. Thus, the role of possessions is limited in the life of the individual;

- All human passions, such as anger, conceit, crookedness, attachment, ego, etc., have their roots in external object which create mental disturbance. Therefore, self control of one's possessions and consumptions is necessary.

Though these presumptions are different from conventional ones, these conditions enable one to establish oneself in aparigraha when one is losing the inner strength of firmly adhering to the ethical principle he has accepted.

There are certain conditions with the help of which the individual can discover the importance of aparigraha in life related to these postulates. These are:

- Awareness of self and destiny; the perishable nature of the material world, the changing nature of the universe;

- The confidence of our self dependence, our competence to handle difficult situations through aparigraha;

- Another condition often mentioned in the Jain scriptures of aparigraha is non-violence, without which the former is not possible. It is a form of social expression of non-violence, and would also include non-violence and chastity in its ambit.

\subsection{Collective Ownership}

One is, however, entitled to achieve ownership not by quarrel or fighting but by collaboration. Thus, Jainism advocates ownership by collaboration, which is expected to keep slavery away from society. In collaborative affair, none is a slave but a partner. Non-observance of this ideal leads to myriad socio-political evils. In the words of Mahavira, "if there were numberless mountains of gold and silver as big as mount Kailasa they would not satisfy an avaricious man, for avarice is boundless like a sky." 


\subsection{Equality}

All talks of Human Rights will fade into unimportance without the presence of equality among people. Therefore, equality is the essential condition for promotion and protection of the rights of the people. Jainism champions the principle of equality and, for that matter, Human Rights in society. Likes should be treated alike-this is what Jain philosophy is based on. Other religions also emphasize it but Jainism is very unambiguous about it.

\subsection{Equality among Caste}

Mahavira sought to establish social equality among four varnas, i.e., castes (based on birth), as was prevalent in Indian society. He laid great stress on the principle of equality among human beings, emphasizing that nature of job and not birth was to be the determining factor of classification, if any.

\subsection{Abolition of Untouchability}

Tirthankara Mahavira and Jain Acharyas launched their attack against the practices that provoked social inequality and social discrimination. They extended full freedom for one and all, including women and Shudras (lower caste). Mahavira's teachings proved to be of great solace to the Shudras, as the practices of social discrimination against them were fully banned. This resulted in the rise of the social status of the downtrodden people. Here we find a similarity with the Western understanding of Human Rights as found in the UN Declaration, where abolition of untouchability was emphasized. Slowly there was a strong opposition to the continuation of the practice of slavery in any form. This was how the right of men not to be treated as slave was mooted by Jainism.

\subsection{Equal Status for Both Men and Women in Education and in Society}

Jainism has made a lasting contribution in the annals of Human Rights by championing the cause of equal status of women and men in society. During the last phase of the Vedic period, women were in fact reduced to the status of Shudras. Like the Shudras, women were debarred from many a right, i.e., the right to pursue religious performances and life. It is worth mentioning here that the princesses as well as other girls were also educated like princes and other boys.

The brief survey from Jain literature as mentioned in the book Jainsystem of Education shows that the Jains were very particular in imparting education to all kinds of people-be they sadhus, kings, princes, princesses, or even laymen.

The basic idea of Jaina education is to impart lessons to individual in order to enable him to build up the character of men and women by practicing some kind of discipline in student life. Throughout its history, the Jain sages and thinkers emphasized this point to a great extent. The main idea of building the character of men and women is to build the character of humanity at large, and through humanity a nation is built up. This is relevant in the contemporary world also.

This is evident in the following extracts, where we get an idea not only of the dignity but also of the apotheosis of women. "Women must be honored and adorned by their fathers, brothers, husbands, and brothers-in-law who desire (their own) welfare." We quote again "where women are honored, there the gods are pleased; but where they are honored, no sacred rite yields rewards.” The above mentioned facts reflect the modern conception of women's right. Therefore, in regard to the status of women, both western and oriental perspectives are similar to a great extent. 


\subsection{Equality and Democracy}

Hence, one can find that Jain philosophy is propounder of the principle of equality: "All men are equal." The fundamental principle of democracy is "All citizens are equal." The principle of democracy is important because the principle of equality is enshrined therein. Here, we see that the philosophy of East and West has merged and one cannot stand without the support of the other in the modern world.

\subsection{Philosophy of Anekant}

It is the unique contribution of the Jaina system of philosophy. The term "ankekantavada" is made up of three words-Aneka (many), anta (aspects or attributes) and vada (ism or theory).

Anekanta consists in multi-sided approach to the study of problems of knowing the truth or reality. This doctrine of relative pluralism was originally propounded in order to strike a balance between two extreme philosophical views between "monism" (the "beings" of the Vedantins) and "nihilism" (the "becoming" of the Buddhists).

The Jains viewed that "all utterances made on something" do not have "an absolute value, but only a relative one and are, therefore, valid only under certain conditions and with certain restrictions."

Radhakrishnan, said, "Modern democracy is based on Mahavira's principles." The main points of Mahavira's doctrine of Anekant are freedom, relativity, equality, and co-existence. These are also the principles of modern democracy. It is the philosophy of the realization of the Supreme Truth. Its practical form is the social system. Mahavira was born in a republican society, and Anekantavad in its practical form is the republican system, which in modern terms is known as pluralist democracy.

In conclusion, we may say that Jainism is very old as a religion, though it is very modern in concept. It is not a religious teaching alone, but a socio-political doctrine as well. Being so, it upholds the cause of the expression of ourselves and fuller development of our personality through the exercise of our rights. Thus, it gives impetus to Human Rights. In a world as of ours, in which discrimination among people or denial of dues to them or exploitation of man by man are as much existent, Jain philosophy seeks to teach us to treat all as decent human beings, equal in need and dignity — to promote and protect the conditions essential and conducive for sustenance of Human Rights and respectable living. If humanity wants to live in peace, respect for Human Rights is essential and Jainism convincingly establishes its importance.

When we compare Human Rights in India and Human Rights in the West, we find some sharp differences as well, due to difference in outlook, education, and socio-political consciousness. Western society is more liberal, non-interfering, and permissive in practice. Due to economic freedom, their approach towards Human Rights is different. They are more concerned with individuality, racial discrimination, and finer elements of social ills whereas our approach is more against exploitation of children, women, and the poorer section of the society. Another problem with our approach to Human Rights is that many cases go unnoticed and unchallenged, whereas the violation of Human Rights in the West generally is quickly exposed and subjected to immediate rectification.

Jainism has some limitations so far Human Rights are concerned. Jains generally belong to a traditional society and are dominated by males in practice. Jains are affluent and they have economic liberty, which puts some limitations on Human Rights approach. Jainism is imbued with a high sense of morality and a different value system. This also imposes some limitation on their approach towards Human Rights. 
The Jain women are most heavily involved in religious activities. Like the performance of samayak and pratikraman, food restriction and fastings are observed by women but when the question of roles, positions, and power comes within the religious sphere, women are excluded. Thus, we find that, in all the temples, committees are run by men.

Outside, the home, amongst the more orthodox sections of the Jain community, as amongst the orthodox sections of the Hindu community, a woman is not expected to work; her role is seen as being firmly rooted in the domestic sphere. As a result, women are economically dependent on their husbands. Even today within smaller towns and villages of Rajasthan, Jain women are expected to cover their head when going outside the home or in the presence of elder male relatives. In social terms, therefore women are clearly regarded as subordinate to man. As a result the implications of the Svetambara, beliefs concerning female equality cannot possibly be realized within the worldly sphere as they would threaten the very power relations between men and women upon which the Indian social fabric is based.

Hence, we find the apparently contradictory ideas which portray women as vehicles of worldly pleasures and sensuality with which they tempt men from the true path and thereby undermine male strength. So in different Jain religious texts, we find the warnings given to monks about the dangers associated with the women. Thus, Sutrakritanga Sutra says, "Therefore he should avoid women, knowing them to be like a poisoned thron." Such derogatory beliefs both reflect male fear concerning female potential and at the same time serve to detract from the high status accorded to women within this Svetambara doctrine. As a result, female motives become clouded with suspicion and it is implied within the religious story literature that women must display exemplary religious and moral conduct if they are to vindicate their spiritual purity and lay claim to their status as the religious equals of men, capable of achieving spiritual perfection.

\section{Works Cited}

Banerjee, S. R. Introducing Jainism. Kolkata: Jain Bhawan, 2002. 2.

Brown, Kerry and Sharma, Sima. That Which Is the Tattvartha Sutra. Umasvati trans. Nathmal Tantia. San Franciso: Harper Collins, 1994. 7.8 (SS. 7.13). 173.

Chapple, Christipher Key. "Religious Dissonance and Reconciliation: The Haribhadra Story.” Ed. Sethia, Tara. Ahimsa, Anekanta and Jainism. Delhi: Motilal Banarsidass, 2004. 150.

Dasgupta, Debandra Chandra. Jaina System of Education. Delhi: Motilal Banarsidass, 1979. 43.

Glasenapp, Halmut Von. Jainism: An Indian Religion and Salvation. Delhi: Motilal Banarsidass, 1999. 170.

Jain, Sagarmal. Saman Suttam. New Delhi: Bhagwan Mahavir Memorial Samiti, 1999. 54.

Jain, Kamal. Aparigraha-The Human Solution. Varanasi: Parsvanatha Vidyapitha, first edition 1998. 86.

Lalwani, K. C. (trans.). Dasavaikalika Sutra. Delhi: Motilal Banarsidass, 1973. iv. (Padhamamnanamtaodaya, evamcitthaisavvasamjae.)

Muni, Nyayavijayaji. Trans. Nagin J. Shah. Jain Philosophy and Religion. Delhi: Motilal Banarsidass, 1998. 112-13.

Niyogi, M. B. “Universality of Jainism.” Ed. Rampuria, S. C. The Heritage of Jainism. Rajasthan: Jain Vishwa Bharati Institute, 2001. 52.

Skoog, Kim. “The Jain Response to Terrorism.” Ed. Sethia, Tara. Ahimsa, Anekanta and Jainism. Delhi: Motilal Banarsidass, 2004. 33.

Shannon, Albert C. The Medieval Inquisition. Collegeville, Minnesoto: The Liturgical Press, 1919. 67; 133.

Sekhar, Vincent. “The Sramana Response to the Human Predicament.” Jain Journal. Vol. XXXIII, No. 2. October, 1998.54.

Sangava,V. Adinath. Facets on Jainology. Bombay: Ramdas Bhatkal, 2001. 20.

Singh, Nagendra Kumar. Encyclopaedia of Jainism. Delhi: Anmol, 2001. 1948. 
Tiwary, Binod Kr. “Relevance of Jain Principles of Mahavira in Modern Context.” Jain Journal. July, 2001. Vol. XXXVI, No. 1. 33.

Tawney, C. H. Kathasaritsagara. Baptist Mission Press, n.d. Vol. I. 195.

Wiley, Kristi. L. "Views on Ahimsa, Compassion, and Samyakva in Jainism.” Ed. Sethia, Tara. Ahimsa, Anekanta and Jainism. Delhi: Motilal Banasidass, 2004. 20. 